\title{
Resistance to Rose Rosette Virus and Transmission Attributes
}

\author{
Patrick L. Di Bello, Thanuja Thekke-Veetil, Tobiasz Druciarek \\ and Ioannis E. Tzanetakis * \\ Department of Plant Pathology, Division of Agriculture, University of Arkansas, Fayetteville, \\ AR 72701, USA; patrick.dibello@gmail.com (P.L.D.B); thanujatv@gmail.com (T.T.V.); \\ tzdrucia@uark.edu (T.D.) \\ * Correspondence: itzaneta@uark.edu; Tel.: +01-479-575-3180
}

\begin{abstract}
Rosette caused by rose rosette virus (RRV) is the most devastating malady of rose in the United States. Because of the recent discovery of the virus and the completion of Koch's postulates all assumptions about the disease are based on visual observations of material that may or may have not been infected by the virus. This study addresses several aspects of virus and disease epidemiology. Twenty rose genotypes were screened for mite and/or virus resistance. Phyllocoptes fructiphilus the only known vector of RRV, was able to establish, lay eggs and develop to nymphs and adults in all genotypes. 'Stormy Weather' shows resistance to the virus as assessed by both mite and cleft-grafting transmission experiments. The acquisition/latent and inoculation access periods were studied revealing long acquisition/latent periods but rapid inoculation time frames. The outputs of this study will assist in the better management of the vector and the disease. The resistant genotype identified could be used in areas with high disease pressure to minimize spread and for identification of the mechanisms behind resistance or as breeding material to incorporate virus resistance to new cultivars. The short inoculation access period indicates that chemical control for the vector may be a challenging undertaking.
\end{abstract}

Keywords: transmission; resistance; detection, Emaravirus

\section{Introduction}

Rose rosette disease (RRD) is the most destructive disease of roses in North America. Early manifestations of RRD include reddened and swollen veins, leaf mosaic and mottling. Emerging shoots remain red for an extended time period when compared to healthy shoots, have an over-abundance of thorns and tend to bunch together, forming witches'-brooms with malformed flowers (Figure 1). Infected roses begin to lose their esthetic appeal and experience an overall decline in vigor resulting in plant death three to five years after the initial infection. 

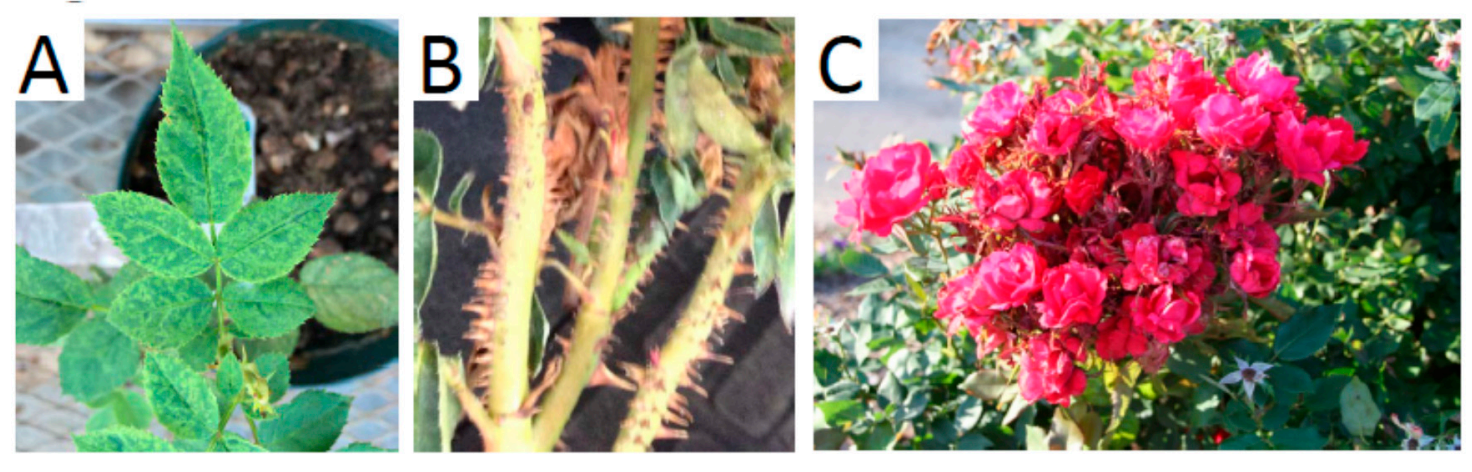

Figure 1. Knock Out ${ }^{\circledR}$ rose infected with rose rosette virus displaying mosaic (A), excessive thorniness (B) or witches'-broom symptoms (C).

Since the 1940s, Rose rosette disease (RRD) has plagued roses across North America [5]. Early epidemiological work found an association between symptoms and eriophyid mites and originally researchers hypothesized that symptoms were caused by mite feeding toxicogenicity [11]. Eriophyid mite-free grafting experiments established that rosette was a transmissible disease [11], but all work was based on symptoms as the rosette agent was unknown but shown to be transmitted by the eriophyid mite Phyllocoptes fructiphilus (Keifer) [1]. While some researchers hypothesized on the viral nature of the agent others considered it a phytoplasma because of the witches' broom and phylloidy symptoms [13]. The linking of double membrane bound bodies and dsRNA to rosette-affected material pointed in the direction of a virus [7]. Laney et al. [18] found rose rosette virus (RRV) in all affected material assayed, which prompted work to determine whether RRV solely or in combination with other viruses caused RRD. Di Bello et al. [9] demonstrated that RRV was transmissible with eriophyid mites and can solely cause typical RRD symptoms fulfilling Koch's postulates for RRD/RRV. In light of this information the characteristics of transmission and resistance were revisited.

RRV belongs to the multipartite, negative strand RNA virus genus Emaravirus. All recognized and tentative emaraviruses have been shown or are hypothesized to be transmitted by eriophyoid mites [4, 16, 20]. Little is known on how emaraviruses interact with their vectors including the mode of transmission. In the case of EMARaV, viral mRNA was detected in Eriophyes pyri suggesting that the virus replicates in the mite [21]. Acquisition and inoculation access periods (IAP and AAP respectively) have been accessed for PPSMV using immunological detection [16].

The basis of any epidemiological study is the development of sensitive, universal protocols. Here we describe such an assay, a RT-PCR, validated on the population structure of more than $130 \mathrm{RRV}$ isolates collected from 19 States in the United States [14]. Using this protocol we were able to screen for resistance to the mite and/or the virus among cultivars commonly grown in the United States. We verified that RRV moves systemically in plants, whereas transmission experiments demonstrated that the virus is transmissible by $P$. fructiphilus with an 
acquisition/latent period of five days and inoculation accession period of one hour or less.

\section{Materials and Methods}

\subsection{Detection}

Oligonucleotide primers were optimized for multiplex PCR of virus and an internal control to ensure quality of nucleic acids and efficient amplification. The most efficient amplification was achieved using primers RRVF (5'GCACATCCAACACTCTTGCAGC-3') and RRVR (5'-CTTATTTGAAGCTGCTCC TTGATTTCC-3'), designed to amplify a 271 bp product in an RNA 3 region with $100 \%$ nucleotide identity among sequenced isolates $[14 ; 18]$ and NADH ND-2F (5' GGACTCCTGACGTATACGAAGGATC3') and NADH ND-2R (5' AGTAGATGCT ATCACACATACAAT 3') that amplify a region of the mRNA or the genomic copy of NADH dehydrogenase ND-2 subunit depending on the quality of the extracted nucleic acids, an important aspect of detection when working with perennial plants $[24,25]$. Total nucleic acids were extracted from infected and RRV-free samples, reverse transcribed and amplified essentially as described in Poudel et al. [23]. This protocol was compared with the one described in Laney et al. [18] using 15 randomly chosen RRV-infected plants collected from different geographic areas at different number of PCR cycles. More than 200 additional RRD samples from Alabama, Arkansas, Delaware, Illinois, Iowa, Kansas, Kentucky, Louisiana, Maryland, Michigan, Missouri, New York, North Carolina, Oklahoma, Pennsylvania, Tennessee, Texas and Virginia were screened to insure broad isolate detection. For routine detection the PCR program consisted of initial denaturation for 2 minutes at $94^{\circ} \mathrm{C}$ followed by 40 cycles of denaturation at $94^{\circ} \mathrm{C}$ for $20 \mathrm{~s}$, annealing at $60^{\circ} \mathrm{C}$ for $20 \mathrm{~s}$ and extension at $72^{\circ} \mathrm{C}$ for $30 \mathrm{~s}$.

\subsection{Systemic movement}

Movement was examined by testing for virus presence in the young roots of 20 RRV-infected plants from the inoculation access period trial in addition to the cleftgrafting experiments, part of the resistance screening, both presented below. Total nucleic acids were extracted as previously described with an additional washing step [23] to minimize the presence of inhibitors that may be present in root tissue and tested for the virus. The absence of inhibitors in the nucleic acid extract was determined by amplification of the mitochondrion cytochrome oxidase subunit I mRNA by RT-PCR before the virus specific test [22]. Virus-specific amplicons were sequenced to confirm results. 


\subsection{Mite and virus resistance screening}

Twenty cultivars, obtained from commercial nurseries, were screened for resistance to the mite and/or the virus. All roses used in the resistance and transmission studies described below were inspected for mites and verified to be RRV-free by RT-PCR prior to initiation of the studies. Roses were maintained in an insect-proof greenhouse and watered, fertilized, and pruned as needed. At least two weeks prior to infestation plants were defoliated to force out new growth. From each field RRV-infected rose used for infestations an average of 50 mites were collected and slide-mounted in modified Berlese medium for phase contrast microscopic examination [2] and all identified as P. fructiphilus [15].

The ability of viruliferous mites to colonize different genotypes was assayed. Mites were collected from RRV-infected roses as assessed by RT-PCR amplification. Fifty adult mites were transferred to leaves of each of the tested genotypes in modified Munger cells [12] using an eyelash tool [6]. Material was kept in growth chambers from $25^{\circ} \mathrm{C}$ to $30^{\circ} \mathrm{C}$ on a $16 \mathrm{~h}$ photoperiod. The presence of mite eggs or immature stages was evaluated seven and fourteen days respectively after the transfer.

Mechanical transmission of RRV is inefficient in rose [17] and for this reason mite and cleft-graft transmission were chosen to evaluate resistance to the virus. Given the recalcitrance of mite transmission, screening was done in two steps: Three to eight plants from each cultivar were inoculated with at least 25 mites and one or two plants were cleft-grafted with two RRV-infected Knock Out ${ }^{\circledR}$ scions. Grafts where kept in a mist chamber for two weeks. New scions were grafted on, when the originals ones did not survive on the rootstock for at least a 30 day period. A cultivar that developed symptoms and tested positive for RRV in either mite or graft transmission was not further evaluated as it was consider susceptible (Table 1). Three cultivars did not develop symptoms and tested negative for RRV in the original screening. For those genotypes additional screening of 35-40 plants was preformed; 25-30 roses of each cultivar were infested with mites and 10 or more plants were grafted with RRV-infected Knock Out ${ }^{\circledR}$ rose scions (Table 1). The presence of the virus was determined using RT-PCR monthly for up to a year post mite infestation or grafting.

Table 1. List of cultivars screened used in the initial (A) and extended (B) screening for resistance to rose rosette virus (RRV) by Phyllocoptes fructiphilus infestation and grafting. In the initial screen if a rose tested positive for RRV by either mite transmission or grafting it was not further screened. 
A

\begin{tabular}{lcc}
\hline & \multicolumn{2}{c}{ No. infected/ no. infested } \\
\cline { 2 - 3 } Cultivar & $\begin{array}{c}\text { Mite } \\
\text { transmission }\end{array}$ & Grafting \\
\hline All Ablaze Cl & $2 / 5$ & $1 / 1$ \\
Bellind's Dream & $1 / 5$ & - \\
Blaze improved Cl & $0 / 5$ & $2 / 2$ \\
Carefree Spirit & $0 / 7$ & $1 / 1$ \\
Double Knock-Out & $1 / 8$ & $1 / 1$ \\
Easy Does it & $1 / 3$ & $1 / 1$ \\
Francis Melliand & $0 / 5$ & $1 / 1$ \\
Iceberg & $1 / 7$ & - \\
Julia Child & $2 / 5$ & - \\
Knock Out & $1 / 6$ & - \\
Marmalade Skies & $3 / 7$ & $1 / 1$ \\
Pink Double Knock Out & $1 / 6$ & - \\
Pink Knock Out & $1 / 6$ & - \\
Queen Elizabeth & $1 / 6$ & - \\
Sunshine Daydream & $1 / 5$ & - \\
Veterans Honor & $1 / 5$ & - \\
Yabba Dabba Doo & $1 / 3$ & - \\
\hline
\end{tabular}

B

\begin{tabular}{lcccccc|ccc}
\hline & \multicolumn{7}{c}{ infected/total } & \multicolumn{3}{c}{ Grafting } \\
\cline { 2 - 10 } & Initial & Exp. 1 & Exp. 2 & Exp. 3 & Exp. 4 & Total & Exp. 1 & Exp. 2 & Total \\
\hline Variety & $0 / 5$ & $0 / 5$ & $0 / 5$ & $1 / 5$ & $0 / 5$ & $1 / 25$ & $1 / 5$ & $1 / 6$ & $1 / 11$ \\
\hline Bonica & $0 / 10$ & $0 / 5$ & $2 / 5$ & $0 / 5$ & $0 / 5$ & $2 / 30$ & $0 / 5$ & $1 / 5$ & $1 / 10$ \\
Home Run & $0 / 5$ & $0 / 5$ & $0 / 5$ & $0 / 5$ & $0 / 5$ & $0 / 25$ & $0 / 5$ & $0 / 5$ & $0 / 10$ \\
Stormy Weather & $0 / 5$
\end{tabular}

\subsection{Transmission attributes}

One-inch 'Julia Child' rose plants, maintained in growth chambers at $25^{\circ} \mathrm{C}$ to $30^{\circ} \mathrm{C}$ on a $16 \mathrm{~h}$ photoperiod were used to determine the acquisition/latent period of the virus. Non-viruliferous mite colonies were established by transferring adult mites to RT-PCR negative RRV rose leaves in modified Munger cells. Adults were allowed to lay eggs and then removed. Hatched larvae were transferred to pest- and RRV-free 'Julia Child' roses. Colony plants were regularly tested for the virus and reared under the above described temperature and light conditions in growth chambers. Mites were transferred to modified Munger cells with RRV-infected leaves, and allowed to feed for 1, 6, 12 and $24 \mathrm{~h}$ or 5 days. Following the respective acquisition time, 25 mites were transferred to a plant node to each of five roses/time point and the experiment was repeated at least three times. Mites were terminated 
14 days after transfer using Worry Free ${ }^{\circledR}$ (0.3\% Pyrethrins and 3\% Piperonyl butoxide) and Sevin ${ }^{\circledast}$ (22.5\% Carbaryl) around the infested nodes and moved to the greenhouse. Experiments for each time point were kept in separate, isolated areas to prevent mite movement in case the chemical control failed to eliminate all individuals. Five additional plants received 25 mites each, directly collected from RRV-free stock colonies to ensure the integrity of the experiment. Roses were monitored for the absence of mites, symptoms and tested for RRV three, six, and twelve months post transmission.

'Julia Child' plants were also used to determine the IAP with plants maintained in growth chambers under the conditions described above. Viruliferous mites were collected from stock colonies in growth chambers under similar conditions or collected directly from infected roses used in the acquisition/latent period experiments. Symptomless and RRV-free roses, as determined after RRV-specific RT-PCR, were infested with 25 mites as described above. To determine the IAP, mites from RRV-infected leaves were transferred to RRV-free roses and allowed to feed for 1, 6 and $12 \mathrm{~h}$ and 1, 5 or 14 days. Mites were terminated as described above. Each trial consisted of five roses and was repeated four times. Seven plants, used as positive controls to insure that vectors were viruliferous, were infested with 25 mites reared on RRV-positive material. Vectors were eliminated a month after infestation with the pesticides mentioned above.

\section{Results}

\subsection{Detection}

The detection of potential asymptomatic infections in the resistance screening was of utmost importance for this work. A universal detection protocol based on the population structure of the virus available to date was developed [14]. In addition, this protocol provides the unique advantage of being multiplexed with an internal control confirming the quality of the nucleic acids, as they may be readily affected in all downstream reactions post extraction and also confirming efficiency of PCR amplification, as it will amplify a 721 base region of the internal control in the absence of virus or a $\sim 1300 \mathrm{bp}$ region of the genomic copy of that gene when there is RNA degradation [24]. We compared several RRV samples using the Laney et al. [18] and the new protocol and the latter provided better amplification consistently, able to detect the virus even at 20 PCR cycles (Figure 2). At least 20 amplicons were sequenced and were all virus-specific, further validating the test. 
A 20 cycles

B

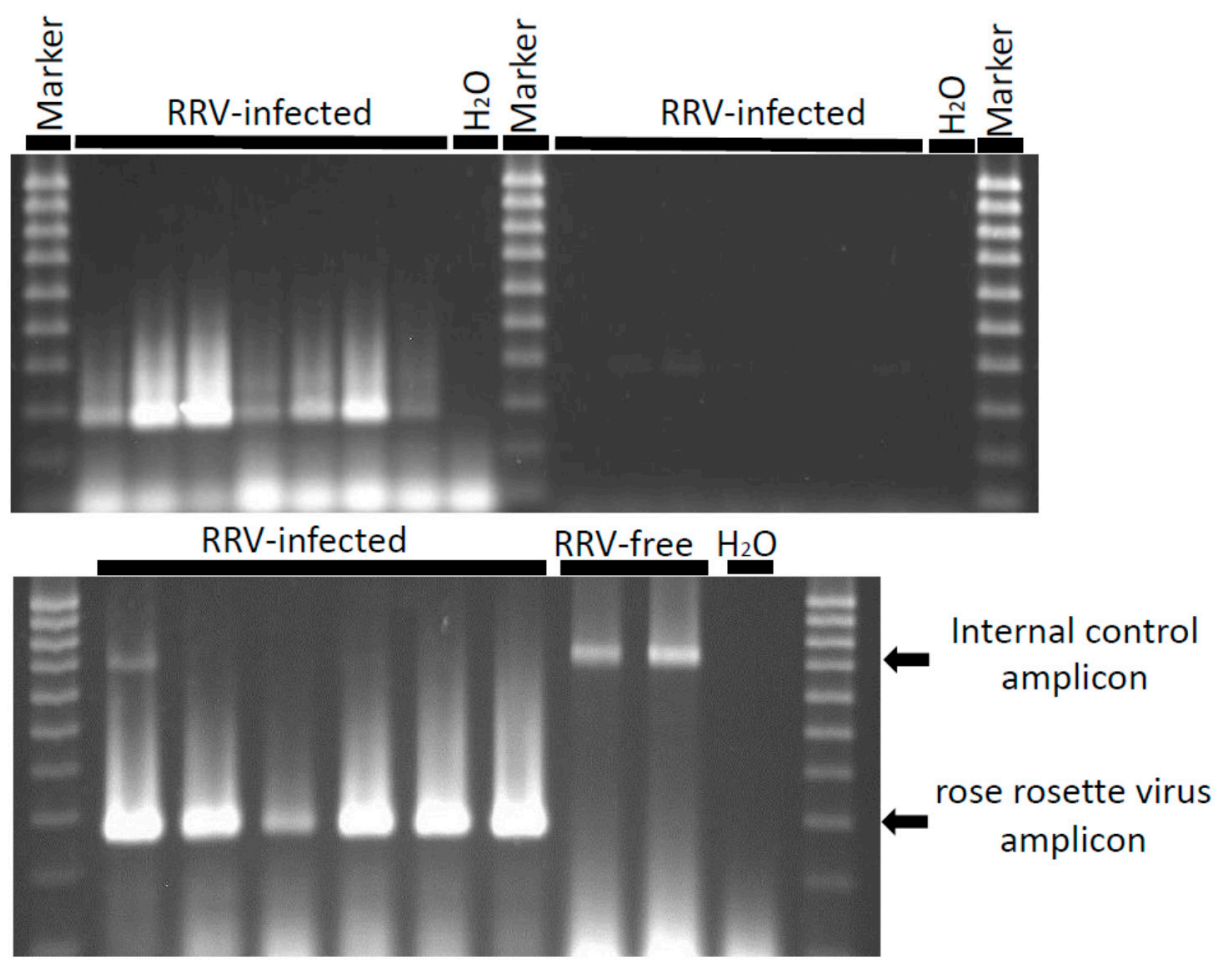

Figure 2. Rose rosette virus (RRV) detection. (A) Comparison of the new RT-PCR (left panels) to the Laney et al. protocol (right panels). Note that the new protocol can detect all isolates after 20 PCR cycles. (B) Routine detection of RRV using the new RT-PCR protocol.

\subsection{Systemic movement}

A total of 20 RRD symptomatic and RRV-positive 'Julia Child' plants were tested for virus movement to the root. All samples amplified the internal control indicating the integrity of RT-PCR and 50\% of the roots tested positive for the virus as determined by sequencing all amplicons.

\subsection{Mite and virus resistance}

Mites were able to lay eggs and immatures developed in all genotypes tested (Figure 3).
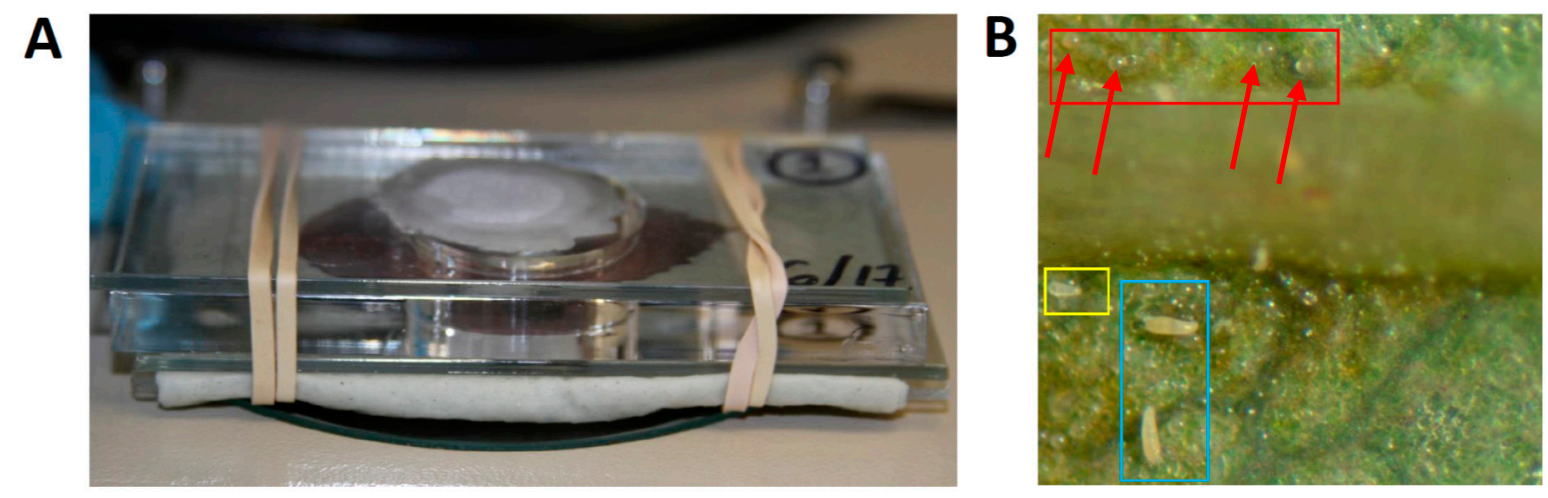
Figure 3. Mite resistance evaluation. (A) Modified Munger cells used in the study; (B) Observation under a stereoscope seven days after transfer of Phyllocoptes fructiphilus adults: red box eggs, yellow box - nymph, blue box - adults

During the initial virus resistance screening seventeen cultivars cleft-grafted and/or infested with viruliferous mites developed symptoms akin with RRD (Table 1) including leaf distortion, vein yellowing, mosaic and mottling (Figure 4), and test positive for the virus. 'Bonica', 'Home Run' and 'Stormy Weather' were further evaluated with the former two eventually proven susceptible; developing typical rosette symptoms (Table 1). 'Stormy Weather' did not sustain virus replication after having tested 35 plants between cleft-graft inoculation and mite transmission.
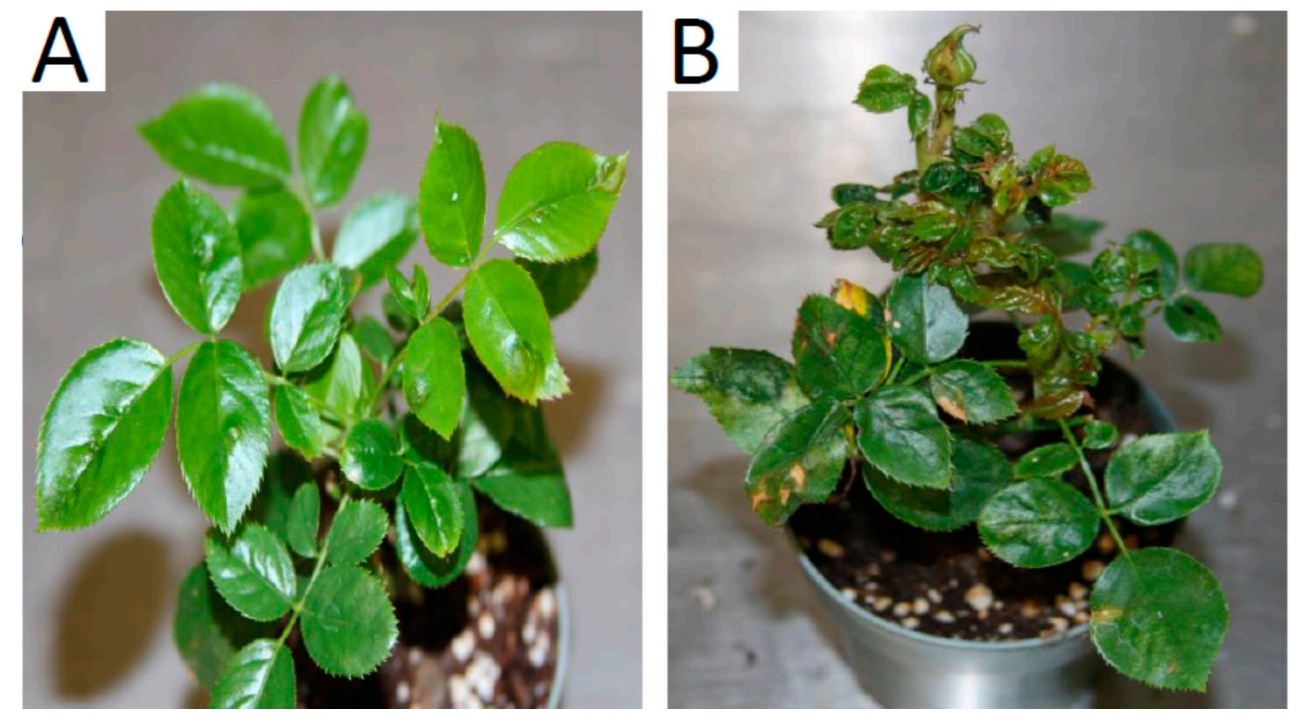

Figure 4. Rose rosette disease symptom progression after mite transmission. (A) Twenty four (24) days post Infestation (PI): enations and leaf distortion; (B) Ninety four (94) days PI: red and distorted newly emerged shoots.

\subsection{Transmission attributes}

In the acquisition/latent period trial a single rose tested positive for RRV when mites were allowed to feed for five days prior to transferring to healthy material (Table 2). Mites successfully transmitted RRV and typical symptoms developed in all IAP time points tested other than six hours (Table 2; Figure 3) with infection ranging between $5 \%$ and $60 \%$. All control plants, where mites were allowed to feed for 30 days, developed symptoms and tested positive for the virus. Symptoms developed in about a month under greenhouse conditions.

Table 2. Rose rosette virus acquisition access/latent and inoculation access periods (A and $\mathrm{B}$ respectively) tested using Phyllocoptes fructiphilus. 
A

\begin{tabular}{cccccc}
\hline & \multicolumn{5}{c}{ infected/infested } \\
\cline { 2 - 6 } $\begin{array}{c}\text { Acquisition } \\
\text { access/latent }\end{array}$ & Exp. 1 & Exp. 2 & Exp. 3 & Exp. 4 & Total \\
\hline 1 hour & $0 / 5$ & $0 / 5$ & $0 / 5$ & - & $0 / 15(0 \%)$ \\
6 hours & $0 / 5$ & $0 / 5$ & $0 / 5$ & - & $0 / 15(0 \%)$ \\
12 hours & $0 / 5$ & $0 / 5$ & $0 / 5$ & - & $0 / 15(0 \%)$ \\
24 hours & $0 / 5$ & $0 / 5$ & $0 / 5$ & $0 / 5$ & $0 / 20(0 \%)$ \\
3 days & $0 / 5$ & $0 / 5$ & $0 / 5$ & $0 / 5$ & $0 / 20(0 \%)$ \\
5 days & $1 / 5$ & $0 / 5$ & $0 / 5$ & $0 / 5$ & $1 / 20(5 \%)$ \\
\hline
\end{tabular}

B

\begin{tabular}{cccccc}
\hline & \multicolumn{5}{c}{ infected/infested } \\
\cline { 2 - 6 } Inoculation access & Exp. $\mathbf{1}$ & Exp. 2 & Exp. 3 & Exp. 4 & Total \\
\hline 1 hour & $1 / 5$ & $0 / 5$ & $0 / 5$ & $0 / 5$ & $1 / 20(5 \%)$ \\
6 hours & $0 / 5$ & $0 / 5$ & $0 / 5$ & $0 / 5$ & $0 / 20(0 \%)$ \\
12 hours & $1 / 5$ & $1 / 5$ & $0 / 5$ & $0 / 5$ & $2 / 20(10 \%)$ \\
24 hours & $1 / 5$ & $2 / 5$ & $2 / 5$ & $1 / 5$ & $6 / 20(30 \%)$ \\
5 days & $2 / 5$ & $0 / 5$ & $3 / 5$ & $5 / 5$ & $10 / 20(50 \%)$ \\
14 days & $1 / 5$ & $1 / 5$ & $5 / 5$ & $5 / 5$ & $12 / 20(60 \%)$ \\
\hline
\end{tabular}

\section{Discussion}

A sensitive multiplex RT-PCR detection protocol, able to detect the virus at low concentrations, was a prerequisite for this study as there was a possibility of asymptomatic infections in the germplasm screened for resistance. We developed a universal RRV detection test based on the accumulated knowledge on the population structure of the virus. Given that the nucleoprotein gene is expected to be transcribed at higher levels than the virus polymerase we hypothesized that RNA 3 would be a better target for the development of the detection protocol. Indeed, the new test is more sensitive when compared to the Laney et al. [18] protocol, able to detect the virus after 20 PCR cycles conferring confidence to the results but also ensure nucleic acids quality (Figure 2). Additional detection protocols for RRV were published after the completion of the research presented here $[3,11]$ and for this reason their sensitivity was not compared with the protocol presented here. Notwithstanding, those protocols are based on sequences of 23 isolates whereas the one presented here has been tested against more than 200 isolates collected from 19 States.

It is often that rosarians only remove symptomatic tissue with the premise that RRV is not systemic and disease could be eliminated by pruning. We used a 'proof-of-concept' approach using cleft-grafting, part of our resistance screening and 
testing root tissue where mites are unable to reach and feed on. Pruning of symptomatic areas does not eliminate the virus and should be avoided to: (i) minimize the persistence of the virus after overwintering in the root system and (ii), as a substitute of plant removal that eliminate the source of viruliferous mites for further spread.

Resistance to any pathogen has many attributes; genotype, virus, environment, vector biology and time. 'Stormy Weather' appears to be resistant under greenhouse conditions which were manipulated for optimal mite survival and symptoms development. These are promising results and 'Stormy Weather', even though is a climbing rose, may be the basis for a control strategy either as material planted in areas with high disease incidence or used in breeding programs to incorporate resistance to new cultivars. Notwithstanding, the cultivar needs to be tested under field conditions and complex virus population structures before any of those actions come into effect.

The study on PPSMV transmission were done using 1-20 mites/plant with transmission ranging from 40-100\% [16]. Using 10 mites/plant the agent was transmitted at $100 \%$ efficiency after $24 \mathrm{~h}$ AAP while needing $2 \mathrm{~h}$ as IAP. In the present study we used a significant higher number of mites/plant and extended the acquisition/latent periods and IAP range to gain additional confidence on the results obtained. Mites require a feeding time of 5 days before becoming viruliferous, an indication that the RRV probably needs to circulate in the mite or even propagate in the mite as suggested in the EMARaV/E. pyri complex [21] whereas mites could retransmit after feeding for less than an hour on RRV-free material. Because of the short IAP, if there is chemical control, it needs to be geared towards modes of action that affects feeding in a short time frame and before the vector is able to transmit the virus.

Further work with a larger set of genotypes needs to be conducted to determine the source or resistance among the parents of the resistant/tolerant cultivars. We aim to continue research with progeny from viruliferous females in order to determine whether transovarial transmission plays a role in the epidemiology of RRV.

Acknowledgments: This work was supported, at least in part, by the Gloeckner Foundation, USDA grant (14-8130-0404-CA) and Hatch project 1002361. The authors would like to thank Dr. A. Katsiani for sharing her results before publication, E. Yates for assistance in transmission, T. Johnson and B. Kanwischer for help with extraction and detection and L. Behnke with Weeks Roses, L. Gragnani and D. Stentzel with Greenheart nursery for providing the rose material.

Author Contributions: P.L.D.B. and I.E.T. conceived and designed the experiments; P.L.D.B., T.T.V. and T.D. performed the experiments; P.L.D.B. and I.E.T. analyzed the data; P.L.D.B. and I.E.T. wrote the paper.

Conflicts of Interest: The authors declare no conflict of interest. 


\section{References}

1. Allington, W.B.; Staples, R.; Viehmeyer, G. Transmission of Rose Rosette virus by eriophyid mite Phyllocoptes fructiphilus. J. Econ. Entomol. 1968, 61, 1137-1140.

2. Amrine, J.; Manson, D. Preparation, mounting and descriptive study of eriophyoid mites. World Crop Pests 1996, 6, 383-396.

3. Babu, B.; Jeyaprakash, A.; Jones, D.; Schubert, T. S.; Baker, C.; Washburn, B., K.; Paret, M.L. Development of a rapid, sensitive TaqMan real-time RT-PCR assay for the detection of Rose rosette virus using multiple gene targets. J. Virol. Meth. 2016, 235, 41-50.

4. Caglayan, K.; Elçi, E.; Serce, C.U.; Kaya, K.; Gazel, M.; Medina, V. Detection of Fig mosaic virus in viruliferous eriophyid mite Aceria ficus. J. Plant Pathol. 2012, 94, 629-634.

5. Conners I.L. In Twentieth Annual Report of the Canadian Plant Disease Survey 1940. Domain of Canada Department of Agriculture Science Service, Division of Botany and Plant Pathology 1941, Ottawa.

6. De Lillo, E.; Craemer, C.; Amrine Jr, J.; Nuzzaci, G. Recommended procedures and techniques for morphological studies of Eriophyoidea (Acari: Prostigmata), in: Eriophyoid Mites: Progress and Prognoses 2010, Springer, 283-307.

7. Di, R.; Hill, J.; Epstein, A. Double Stranded RNA associated with the Rose Rosette disease of Multiflora Rose. Plant Dis., 1990, 74, 56-58.

8. Di Bello, P.L.; Laney, A.G.; Druciarek, T.; Ho, T.; Gergerich, R.C.; Keller, K.E.; Martin, R.R.; Tzanetakis, I.E. A novel emaravirus is associated with redbud yellow ringspot disease. Virus Res. 2016, 222, 41-47.

9. Di Bello, P.L.; Ho, T.; Tzanetakis, I.E. The evolution of emaraviruses is becoming more complex: seven segments identified in the causal agent of Rose rosette disease. Virus Res. 2015, 210, 241-244.

10. Dobhal, S.; Olson, J.D.; Arif, M.; Suarez, J.A.G.; Ochoa-Corona, F.M. A simplified strategy for sensitive detection of Rose rosette virus compatible with three RTPCR chemistries. J. Virol. Meth. 2016, 232, 47-56.

11. Doudrick, R.; Millikan, D. Some etiological and symptomological aspects of Rose Rosette. Phytopathology 1983, 73, 840.

12. Druciarek, T.; Lewandowski, M.; Kozak, M. Demographic parameters of Phyllocoptes adalius (Acari: Eriophyoidea) and influence of insemination on female fecundity and longevity. Exp. Appl. Acarol. 2014, 63, 349-360.

13. Epstein, A.; Hill, J. The biology of Rose Rosette Disease - A mite associated disease of uncertain etiology. J. Phytopathol., 1995, 143, 353-360.

14. Katsiani A.; and Tzanetakis I.E. Population structure of rose rosette virus. In preparation

15. Keifer H.H. Eriophyid Studies VIII. Bull. Calif. Dept. Agr. 1940, 29, 21-46.

16. Kulkarni, N.; Kumar, P.L.; Muniyappa, V.; Jones, A.T.; Reddy, D. Transmission of Pigeon pea sterility mosaic virus by the eriophyid mite, Aceria cajani (Acari: Arthropoda). Plant Dis., 2002, 86, 1297-1302. 
17. Laney, A.G. Characterization of the causal agents of Rose rosette and Redbud yellow ringspot. M.S. Thesis, University of Arkansas, 2010.

18. Laney, A.G.; Keller, K.E.; Martin, R.R.; Tzanetakis, I.E. A discovery 70 years in the making: characterization of the Rose rosette virus. J. Gen. Virol., 2011, 92, 17271732.

19. Melzer, M.; Sugano, J.; Uchida, J.; Kawate, M.; Borth, W.; Hu, J. Partial characterization of a novel emara-like virus from Cordyline fruticosa (L.) with ti ringspot disease. Phytopathology, 2014, 104, S79.

20. Mielke-Ehret, N.; Muehlbach, H.-P. Emaravirus: A Novel Genus of Multipartite, Negative Strand RNA Plant Viruses. Viruses, 2012, 4, 1515-1536.

21. Mielke-Ehret, N.; Thomas, J.; Schlatermund, N.; Muehlbach, H.-P. Detection of European mountain ash ringspot-associated virus-specific RNA and protein P3 in the pear leaf blister mite Phytoptus pyri (Eriophyidae). Arch. Virol., 2010, 155, 987991.

22. Papayiannis, L.C.; Harkou, I.S.; Markou, Y.M.; Demetriou, C.N.; Katis, N.I. Rapid discrimination of Tomato chlorosis virus, Tomato infectious chlorosis virus and co-amplification of plant internal control using real-time RT-PCR. J. Virol. Meth. 2011; 176, 53-59.

23. Poudel, B.; Wintermantel, W.M.; Cortez, A.A.; Ho, T.; Khadgi, A., Tzanetakis, I. E. Epidemiology of Blackberry yellow vein associated virus. Plant Dis., 2013, 97, 13521357.

24. Thekke-Veetil, T.; Ho, T.; Moyer, C.; Whitaker V.M.; Tzanetakis, I.E. Detection of Strawberry necrotic shock virus using conventional and TaqMan ${ }^{\circledR}$ quantitative RT-PCR. J.Virol. Meth., 2016, 235, 176-181.

25. Tzanetakis, I.E.; Postman, J.D.; Martin, R.R. Identification, detection and transmission of a new Vitivirus from Mentha. Arch. Virol., 2007, 152, 2027-2033.

(C) 2016 by the authors; licensee Preprints, Basel, Switzerland. This article is an open access article distributed under the terms and conditions of the Creative Commons by Attribution (CC-BY) license (http://creativecommons.org/licenses/by/4.0/). 